NBER WORKING PAPER SERIES

\title{
A SMALL CORNER OF INTERTEMPORAL PUBLIC FINANCE - NEW DEVELOPMENTS IN MONETARY ECONOMICS: TWO GHOSTS, TWO ECCENTRICITIES, A FALLACY, A MIRAGE AND A MYTHOS
}

\author{
Willem H. Buiter \\ Working Paper 10524 \\ http://www.nber.org/papers/w10524 \\ NATIONAL BUREAU OF ECONOMIC RESEARCH \\ 1050 Massachusetts Avenue \\ Cambridge, MA 02138 \\ May 2004
}

Paper for the 2004 Hahn Lecture, given on 6 April 2004 at the Royal Economic Society Annual Conference, Swansea, UK. The views expressed are those of the author. They do no represent the views of the European Bank for Reconstruction and Development. I would like to thank David Hendry, Steve Nickell, Anne Sibert and John Sutton for helpful discussions on the subject matter of this lecture. The views expressed herein are those of the author(s) and not necessarily those of the National Bureau of Economic Research.

(C2004 by Willem Buiter. All rights reserved. Short sections of text, not to exceed two paragraphs, may be quoted without explicit permission provided that full credit, including $\mathbb{C}$ notice, is given to the source. 
A Small Corner of Intertemporal Public Finance - New Developments in Monetary Economics: Two Ghosts, Two Eccentricities, A Fallacy, A Mirage and a Mythos

Willem H. Buiter

NBER Working Paper No. 10524

May 2004

JEL No. E0, E4, E5, E6

\section{$\underline{\text { ABSTRACT }}$}

Monetary theory and policy are part of intertemporal public finance. The lecture reviews some interesting recent developments. The two ghosts are the venerable liquidity trap and the Pigou effect or real balance effect. The eccentricities are negative nominal interest rates and the helicopter drop of base money - two unconventional policies for stimulating consumer demand even when nominal interest rates, short and long, present and future, are at their zero lower bounds. The fallacy is the so-called Fiscal Theory of the Price Level, a logically in-consistent theory of the link between the government budget and the general price level. The mirage is the prediction that financial deregulation and technical change in the payments and settlements technology (e-money etc.), will cause monetary policy to lose its capacity to influence even nominal economic variables. Mythos refers to the independent central bank.

Willem H. Buiter Office of the Chief Economist

European Bank for Reconstruction and Development

One Exchange Square

London EC2A 2EH

UNITED KINGDOM

and NBER

willembuiter@whsmithnet.co.uk 


\section{Introduction}

This lecture reviews some recent developments in monetary theory, monetary policy and the design of institutions for conducting monetary policy. I hope to convey the following messages: (1) Monetary theory is a thriving and exciting area of research (2) Monetary policy is, conceptually, institutionally and practically, a small but significant part of intertemporal public finance - its liquid corner. Central bank operational independence and other institutional arrangements and ongoing developments relevant to the conduct of monetary policy should not blind one to the fundamental truth that monetary policy is but one component of the fiscal-financial-monetary programme of the state - the sovereign. Fundamentally, there can be no such thing as an independent central bank. For the central bank to perform well, it needs to be backed by and backed up by an effective fiscal authority. In this relationship, the central bank is, inevitably, the junior partner.

As regards the subtitle of this lecture, the two ghosts are the venerable liquidity trap and the Pigou effect (or real balance effect). Both have resurfaced as issues to be studied by monetary theorists and macroeconometricians, and as policy concerns for central bankers facing a deflationary environment and the threat or reality of the zero lower bound on nominal interest rates. The two eccentricities are negative nominal interest rates and the theoretical rationale for and practical modalities of performing Milton Friedman's helicopter drop of irredeemable base money. These two unconventional policies can stimulate consumer demand even when nominal interest rates, short and long, present and future, are all at their zero lower bounds and Svensson's 
[43] 'foolproof' methods fail.

The fallacy is the so-called Fiscal Theory of the Price Level (FTPL), an unconventional theory of the link between the government budget and the general price level that became popular in the 1990s. Its basic theoretical flaw - treating the government's intertemporal budget constraint as an equilibrium condition that determines the general price level rather than a relationship that has to hold identically - results generically (and not surprisingly) in an ill-posed equilibrium, even in the canonical FTPL setting, when government pegs the nominal interest rate. Because important links exist, in well-posed dynamic monetary general equilibrium models, between the government's fiscal-financial-monetary programme (FFMP) and the dynamics of the price level and the real value of the public debt, and because some of the influence of the FTPL may still linger, it makes sense to use the opportunity provided by this Hahn lecture to perform a post-mortem on the FTPL and extol the virtues of the CTPL - the consistent, coherent and conventional theory of the price level. This rejection of the FTPL is not a matter of 'de gustibus...' or an empirical issue. It is a matter of logical coherence and consistency.

The mirage is the vision of the future of government fiat money and monetary policy which holds that a combination of financial deregulation and technical change in the payments and settlements technologies (electronic funds transfer, e-money, cash-on-a chip etc.) will cause monetary policy to lose its capacity to influence nominal, let alone real economic variables. This view fails to appreciate the unique capacity of the state to provide unquestioned and unlimited liquidity (through its monopoly of the power to tax, regulate and endow some of its liabilities with legal tender status) when, 
because of systemic risk and uncertainty, the private provision of liquidity dries up.

Finally, the mythos refers to the theoretical rationale for and institutional implementation of central bank independence. The word mythos' is applicable in all its senses, from a fictitious story, fiction or half-truth, through a popular belief to the pattern of basic values and attitudes of a people. Although, fundamentally, there can be no such thing as independence for the central bank, the institutional arrangements and operating characteristics now commonly grouped together under the 'operational independence' label have by and large been helpful in delivering better monetary policies than most practical alternatives. However, misinterpretation of the meaning of independence for central banks can lead to policy conflict, poorly designed and executed monetary and fiscal policies and to financial instability.

\section{A monetary general equilibrium model}

Consider a closed endowment economy with a single perishable commodity. Every period $t \geq 1$ each household receives an exogenous endowment $y_{t}>0$, pays net lump-sum taxes $\tau_{t}$, and consumes $c_{t} \geq 0$. There are three financial claims, fiat base money, one-period nominal bonds and one-period real bonds. The actual quantities outstanding at the end of period $t$ and carried into period $t+1$ are, respectively, $M_{t}, B_{t}$ and $d_{t}$. Quantities demanded by households have a superscript $p$; quantities supplied by the government have a superscript $g$. Also $m_{t} \equiv M_{t} / P_{t}$ and $b_{t} \equiv B_{t} / P_{t}$. Money held from period $t$ to $t+1$ bears a risk-free nominal interest rate $i_{t+1}^{M}>-1$. The 
risk-free nominal and real interest rates on non-monetary financial instruments (nominal, respectively real bonds) held from period $t$ to $t+1$ are $i_{t+1}>-1$, respectively $r_{t+1}>-1$. The period $t$ money price of the commodity is $P_{t} \geq 0$. Total non-monetary contractual debt of the government outstanding at the beginning period $t+1$ (including interest due) is denoted $F_{t+1} \equiv\left(1+i_{t+1}\right) B_{t}+P_{t+1}\left(1+r_{t+1}\right) d_{t}$ and $f_{t+1} \equiv F_{t+1} / P_{t+1}$.

Households strictly observe all contractual obligations vis-à-vis other households. The government, however, can 'override' its outstanding (predetermined) contractual financial obligations vis-à-vis the private sector. Without this affecting the substance of anything that follows, we also assume that the government always honours its monetary contractual obligations. The government also always implements its public spending and tax programme.

If the government does not honour its contractual debt obligations at the beginning of period $t+1$, all outstanding debt has equal seniority, that is, all resources available for debt service are pro-rated equally over all outstanding non-monetary contractual debt: the government, in period $t+1$ will pay $V_{t+1} F_{t+1}$ on its outstanding non-monetary debt. If $0 \leq V_{t+1}<1$, then $V_{t+1}$ has the interpretation of a government debt default discount factor - the fraction of the contractual payments due in period $t+1$ that is actually paid. We may also wish to consider $V_{t+1}>1$ (a government debt super-solvency premium). and $V_{t+1}<0$ (the government's contractual debt is revalued into an effective credit, or vice versa). To make sense of these last two possibilities, public debt would have to viewed as equity (without limited liability, if we permit $V_{t+1}<0$ ), in the present discounted value of the future primary surpluses (including seigniorage) of the government. To encompass all these 
cases, I refer to $V_{t+1}$ as the public debt revaluation factor in period $t+1$. Households take $V_{t+1}$ as given.

Nominal effective non-monetary debt at the beginning of period $t+1$ is $V_{t+1} F_{t+1}$; real effective non-monetary debt is $V_{t+1} f_{t+1}$. Total effective monetary and non-monetary contractual obligations of the government (including interest due) at the beginning of period $t+1$ are denoted $A_{t+1} \equiv\left(1+i_{t+1}^{M}\right) M_{t}+$ $V_{t+1} F_{t+1}$ and $a_{t+1} \equiv A_{t+1} / P_{t+1}$. Only the government can issue base money, so $M_{t}^{p}, M_{t}^{g}, M_{t} \geq 0$.

\subsection{Households}

The period $t$ budget identity of the representative household is

$$
\begin{aligned}
& \frac{M_{t}^{p}}{P_{t}}+V_{t+1}\left(\frac{B_{t}^{p}}{P_{t}}+d_{t}^{p}\right) \\
\equiv & {\left[\left(1+i_{t}^{M}\right) \frac{M_{t-1}^{p}}{P_{t}}+V_{t}\left(\left(1+i_{t}\right) \frac{B_{t-1}^{p}}{P_{t}}+\left(1+r_{t}\right) d_{t-1}^{p}\right)\right]+y_{t}-\tau_{t}-c_{t}, t \geq 1 }
\end{aligned}
$$

Arbitrage equates the risk-free rates of return on nominal and real government debt:

$$
\left(1+r_{t+1}\right) \frac{P_{t+1}}{P_{t}}=1+i_{t+1}, t \geq 1
$$

We rewrite the period $t$ household budget identity as

$$
a_{t}^{p} \equiv \frac{1}{1+r_{t+1}} a_{t+1}^{p}+c_{t}+\tau_{t}-y_{t}+m_{t}^{p}\left(\frac{i_{t+1}-i_{t+1}^{M}}{1+i_{t+1}}\right)
$$


Define the real discount factor from period $t_{0}$ to $t_{1}$ as follows:

$$
R_{t_{0}, t_{1}} \equiv \prod_{s=t_{0}}^{t_{1}}\left(1+r_{s}\right)^{-1} \quad t_{1} \geq t_{0} ; R_{t_{0}, t_{0}-1} \equiv 1
$$

The following assumption is crucial:

Assumption 1: Base money is perceived to be an asset by each individual household. Households believe they can always realise this asset in any period, including the infinitely distant future, at the prevailing market price of money.

The household solvency constraint is accordingly that the present discounted value of its terminal financial assets (monetary and non-monetary) be non-negative:

$$
\lim _{N \rightarrow \infty} R_{t+1, N} a_{N}^{p} \geq 0
$$

In each period, $t$, the household maximises the utility function given in (4), subject to (2) and (3), taking as given that period's public debt revaluation factor $V_{t}$ and the initial contractual financial asset stocks $M_{t-1}=$ $\bar{M}_{t-1}>0 ; B_{t-1}=\bar{B}_{t-1}$ and $b_{t-1}=\bar{b}_{t-1}$.

$$
\sum_{j=t}^{\infty}\left(\frac{1}{1+\rho}\right)^{j-t} u\left(c_{j}, m_{j}^{p}\right) ; \rho>0, c_{j}, m_{j}^{p} \geq 0
$$

The period felicity function is increasing in consumption and end-ofperiod real money balances, strictly concave, twice continuously differentiable and satisfies the Inada conditions for consumption and real money balances.

Necessary and sufficient conditions for a household optimal programme 
are:

$$
\begin{gathered}
u_{c}\left(c_{t}, m_{t}^{p}\right)=\left(\frac{1+r_{t+1}}{1+\rho}\right) u_{c}\left(c_{t+1}, m_{t+1}^{p}\right) \\
u_{m}\left(c_{t}, m_{t}^{p}\right)=\left(\frac{i_{t+1}-i_{t+1}^{M}}{1+i_{t+1}}\right) u_{c}\left(c_{t}, m_{t}^{p}\right) \\
\lim _{N \rightarrow \infty}(1+\rho)^{-(N-t)} u_{c}\left(c_{N}, m_{N}^{p}\right) a_{N}^{p}=0
\end{gathered}
$$

Because $u_{c}>0$ for bounded values of $c$, equations (7) and (5) imply that the household solvency constraint (3) will hold with equality. This means that we can solve (3) and (2) for the household intertemporal budget constraint (HIBC) in (8):

$$
\begin{aligned}
& \frac{\left(1+i_{t}^{M}\right) M_{t-1}^{p}}{P_{t}}+V_{t}\left(\frac{\left(1+i_{t}\right) B_{t-1}^{p}}{P_{t}}+\left(1+r_{t}\right) d_{t-1}^{p}\right) \equiv \\
& \sum_{j=t}^{\infty} R_{t+1, j}\left[c_{j}+\tau_{j}-y_{j}+\left(\frac{i_{j+1}-i_{j+1}^{M}}{1+i_{j+1}}\right) m_{j}^{p}\right]
\end{aligned}
$$

For expositional simplicity, I will assume in most of what follows that the period felicity function takes the following form.

$$
u\left(c_{t}, m_{t}^{p}\right)=(1-\alpha) \ln c_{t}+\alpha m_{t}^{p}, 0<\alpha<1
$$

A drawback of this specification is that there no satiation in real money balances at a finite stock of real money balances. ${ }^{1}$

\footnotetext{
${ }^{1}$ Indeed, utility increases in real money balances without bound.
} 


\subsection{Government}

The government's period budget identity is given in (10). Real public spending on goods and services is denoted $g$. 'Government' refers to the consolidated central bank and general government, that is, it refers to the state or the sovereign as a whole.

$$
\begin{aligned}
& M_{t}^{g}+V_{t+1}\left(B_{t}^{g}+P_{t} d_{t}^{g}\right) \\
\equiv & \left(1+i_{t}^{M}\right) M_{t-1}^{g}+V_{t}\left[\left(1+i_{t}\right) B_{t-1}^{g}+P_{t}\left(1+r_{t}\right) d_{t-1}^{g}\right]+P_{t}\left(g_{t}-\tau_{t}\right)
\end{aligned}
$$

We can rewrite (10) as

$$
V_{t} f_{t}^{g} \equiv \frac{1}{1+r_{t+1}} V_{t+1} f_{t+1}^{g}+\tau_{t}-g_{t}+s_{t}^{g}
$$

where $s_{t}^{g} \equiv \frac{M_{t}^{g}-\left(1+i_{t}^{M}\right) M_{t-1}^{g}}{P_{t}}$ is the real value of period $t$ seigniorage income (the real value of net new base money issuance over and above the interest bill on the outstanding stock of base money). A second key assumption is the following:

Assumption 2: Base money does not have to be redeemed by the government - ever. It does not represent a claim by the holder on the issuer for anything other than the same amount of itself.

An implication of Assumption 2 is that the government's solvency constraint requires the present discounted value of its non-monetary terminal liabilities to be non-positive: 


$$
\lim _{N \rightarrow \infty} R_{t+1, N} V_{N} f_{N}^{g} \equiv \lim _{N \rightarrow \infty} R_{t+1, N} V_{N}\left(\left(1+i_{N}\right) \frac{B_{N-1}^{g}}{P_{N}}+\left(1+r_{N}\right) d_{N-s}^{g}\right) \leq 0
$$

Together, (12) and (11) imply the government's intertemporal budget constraint (GIBC). It is assumed to hold with equality.

$$
V_{t}\left(\frac{\left(1+i_{t}\right) B_{t-1}^{g}}{P_{t}}+\left(1+r_{t}\right) d_{t-1}^{g}\right) \equiv \sum_{j=t}^{\infty} R_{t+1, j}\left[\tau_{j}-g_{j}+s_{j}^{g}\right]
$$

Assumptions 1 and 2 together formalise the monetary folk proposition that (government fiat) money is an asset to the private holder but not in any meaningful sense a liability of the public issuer.

\subsubsection{The government's fiscal-financial-monetary programme}

Real government spending on goods and services is constant:

$$
g_{t}=g \geq 0, t \geq 1
$$

The nominal interest rate on base money is constant:

$$
i_{t}^{M}=i^{M}, t \geq 1
$$

Two alternative monetary rules are considered. 
(1) A constant growth rate for the nominal money stock:,

$$
\begin{aligned}
M_{t+1}^{g} & =(1+v) M_{t}^{g}, t \geq 0 \\
1+v & \geq \frac{1+i^{M}}{1+\rho}
\end{aligned}
$$

(2) A constant nominal interest rate:

$$
i_{t}=i \geq i^{M}, t \geq 1
$$

Two tax rules are considered.

(1) A simple 'Ricardian' rule that aims to ensure that the GIBC holds identically, that is, for all feasible values of the variables entering the GIBC, when the government is committed to contract fulfillment. The Ricardian tax rule in (18) has taxes adjusting endogenously or 'residually' to keep constant the real value of the total financial liabilities, monetary and non-monetary, of the government: $a_{t+1}^{g}=a_{t}^{g}=a_{0}, t \geq 1$. This implies the following behaviour for taxes:

$$
\tau_{t}=g+\frac{r_{t+1}}{1+r_{t+1}} a_{0}+\frac{i^{M}-i_{t+1}}{1+i_{t+1}} m_{t}^{g}, t \geq 1
$$

(2) A simple 'Non-Ricardian' or overdetermined rule that keeps constant the real value of taxes plus seigniorage each period at some exogenously given value:

$$
\tau_{t}=\bar{\tau}-s_{t}^{g}, t \geq 1
$$

According to the CTPL the GIBC always holds identically. Either the government is committed to contract fulfillment, that is, 


$$
V_{t}=1, t \geq 1
$$

in which case it adopts the Ricardian rule (18). Alternatively, it adopts the ('overdetermined') non-Ricardian rule (19), in which case $V_{t}, t \geq 1$ is endogenous and $V_{t} f_{t}, t \geq 1$ 'clears' the GIBC. Both approaches lead to a well-posed general equilibrium system.

The FTPL, which leads to ill-posed general equilibrium systems, requires that the government's intertemporal budget constraint hold only as an equilibrium condition. It assumes that the (overdetermined) non-Ricardian fiscal rule (19) applies, but nevertheless insists on contract fulfillment $\left(V_{t}=1, t \geq\right.$ 1). According to the FTPL, the government can always satisfy its contractual debt obligations exactly, despite its overdetermined FFMP, because in each period, $t$, the general price level $P_{t}$ plays the same role revaluing the government's non-monetary debt, as is played by $V_{t} f_{t}$ in the CTPL (that is, under the non-Ricardian fiscal rule without contract fulfillment). ${ }^{2}$

\subsection{Equilibrium}

The private sector and the government have consistent views on and expectations of current and anticipated future financial asset stocks, except possibly "at infinity". This is the meaning of equations (21a) to (21d). The potential asymmetry or discrepancy between the public and private sectors' views on

\footnotetext{
${ }^{2}$ In a world without uncertainty or in a world with uncertainty and complete contingent markets, the requirement that contracts be fulfilled exactly does not pose problems. Let $\Omega_{t}$ be the set of states of nature in period $t$. Then in every period $t, V_{\omega_{t}}=1 \forall \omega_{t} \in \Omega_{t}$. In a world with uncertainty but incomplete markets, weaker requirements such as expected contract fulfillment would have to be introduced.
} 
the present discounted value of terminal fiat money balances cannot be verified and resolved, since it involves the behaviour of the money stock in the limit as $t \rightarrow \infty$.

$$
\begin{array}{ll}
a_{t}^{p}=a_{t}^{g}=a_{t}, & t \geq 0 \\
f_{t}^{p}=f_{t}^{g}=f_{t} & , t \geq 0 \\
s_{t}^{g}=s_{t} & , t \geq 1
\end{array}
$$

$\lim _{N \rightarrow \infty} R_{t+1, N} a_{N}^{g}=\lim _{N \rightarrow \infty} R_{t+1, N}\left(1+i^{M}\right) \frac{M_{N-1}^{g}}{P_{N}}=\lim _{N \rightarrow \infty} R_{t+1, N}\left(1+i^{M}\right) \frac{M_{N-1}}{P_{N}}$

The endowment is exogenous and constant, $y_{t}=y^{*}>g \geq 0$. Prices are flexible and the goods market clears each period:

$$
c_{t}=y^{*}-g, t \geq 1
$$

With the separable period felicity function, the equilibrium real interest rate is constant

$$
r_{t}=\rho, t \geq 1
$$

With a log-linear period felicity function, monetary equilibrium is given by:

$$
y^{*}-g=\left(\frac{1-\alpha}{\alpha}\right)\left(\frac{i_{t+1}-i^{M}}{1+i_{t+1}}\right) \frac{M_{t}}{P_{t}}, i_{t+1} \geq i^{M}, t \geq 1
$$




$$
\begin{gathered}
1+i_{t+1}=(1+\rho) P_{t+1} / P_{t}, t \geq 1 \\
V_{t}\left(\frac{\left(1+i_{t}\right) B_{t-1}}{P_{t}}+\left(1+r_{t}\right) d_{t-1}\right) \equiv \sum_{j=t}^{\infty}\left(\frac{1}{1+\rho}\right)^{j-t}\left[\tau_{j}-g+s_{j}\right], t \geq 1 \\
s_{t} \equiv \frac{M_{t}-\left(1+i^{M}\right) M_{t-1}}{P_{t}}, t \geq 1 \\
M_{0}=\bar{M}_{0}>0 ; B_{0}=\bar{B}_{0} ; d_{0}=\bar{d}_{0} ; i_{1}=\bar{\imath}_{1} ; r_{1}=\bar{r}_{1}
\end{gathered}
$$

As pointed out in Section 2.2.1, the CTPL permits two kinds of equilibria. The first has contract fulfillment by the government, that is, (20) holds, and the Ricardian tax function (18) applies. In equilibrium this tax function can be written as

$$
\tau_{t}=g+\frac{\rho}{1+\rho} a_{0}-\frac{\alpha}{1-\alpha}\left(y^{*}-g\right), t \geq 1
$$

In equilibrium with contract fulfillment, the GIBC in period $t \geq 1$ is:

$$
f_{t} \equiv \frac{\left(1+i_{t}\right) B_{t-1}}{P_{t}}+\left(1+r_{t}\right) d_{t-1} \equiv \sum_{j=t}^{\infty}\left(\frac{1}{1+\rho}\right)^{j-t}\left[\tau_{j}-g+s_{j}\right]
$$

The second CTPL equilibrium does not impose contract fulfillment. The government adopts the non-Ricardian tax function given in (30) and $V_{t}$ is 
endogenous.

$$
\tau_{t}=\bar{\tau}-s_{t}, t \geq 1
$$

The GIBC becomes:

$$
\begin{aligned}
V_{t} f_{t} & \equiv V_{t}\left(\frac{\left(1+i_{t}\right) B_{t-1}}{P_{t}}+\left(1+r_{t}\right) d_{t-1}\right) \\
& \equiv \sum_{j=t}^{\infty}\left(\frac{1}{1+\rho}\right)^{j-t}\left[\tau_{j}-g+s_{j}\right]=\frac{1+\rho}{\rho}(\bar{\tau}-g), t \geq 1 .
\end{aligned}
$$

In the second CTPL equilibrium, $V_{t} f_{t}$, the effective real value of the government's net non-monetary debt is 'residually' determined from the GIBC. Note that the GIBC still holds identically. Also, while $V_{t} f_{t}$ is always uniquely determined from (31), whether $V_{t}$ and $f_{t}$ are severally determinate depends both on the monetary policy regime and on the composition of the outstanding non-monetary financial liabilities of the government.

Until Section 5, I will assume that the government adopts the Ricardian fiscal rule with contract fulfillment. 


\section{The real balance effect and the liquidity trap}

The log-linear utility function (9) implies the following consumption function:

$$
c_{t}=(1-\alpha)\left(\frac{\rho}{1+\rho}\right)\left(a_{t}+\sum_{j=t}^{\infty} R_{t+1, j}\left(y_{j}-\tau_{j}\right)\right)
$$

Substituting the GIBC (29) into the household consumption function (32), using the definition of seigniorage (27) and the monetary equilibrium condition (24), we obtain the consumption function "after consolidation of the HIBC and the GIBC":

$$
c_{t}=\frac{\rho}{1+\rho}\left(\sum_{j=t}^{\infty} R_{t+1, j}\left(y_{j}-g_{j}\right)+P_{t}^{-1} \lim _{N \rightarrow \infty} I_{t+1, N}\left(1+i^{M}\right) M_{N-1}\right)
$$

It is well-known that a representative agent model necessarily exhibits debt neutrality or Ricardian equivalence: government non-monetary debt is not net wealth. Philippe Weil [44] pointed out that in the representative agent model fiat government money would not be net wealth either. His consumption function would have been $c_{t}=\frac{\rho}{1+\rho} \sum_{j=t}^{\infty} R_{t+1, j}\left(y_{j}-g_{j}\right)$. With symmetric household and government solvency constraints, there is no real balance effect or Pigou effect on private consumption. Monetary policy does not work through any wealth effect. It can only affect real consumption if it changes the present value of future endowments (holding constant the sequence of current and future real government spending). It can do so either 
by changing current and future real interest rates, and thus the real discount factors, or by somehow changing the sequence of current and future real endowments. ${ }^{3}$

With irredeemable government fiat money, base money is net wealth in the sense that the present discounted value of the terminal stock of money balances is part of the private sector's comprehensive wealth after consolidation of the HIBC and GIBC. Thus, there exists a weak form of the real balance effect even in the representative agent model with rational expectations.

A helicopter drop of money in period $t$ is an increase in the period $t$ stock of nominal base money brought about by a reduction in period $t$ taxes. There is a pure wealth effect of monetary policy on consumption demand if changes in the sequence of current and future nominal money stocks can change consumption demand, holding constant the initial price level, initial financial asset stocks, the sequences of current and future nominal and real interest rates, real government spending, and endowments. It follows from a comparison of equations (32) and (33) that there is a pure wealth effect of monetary policy only if monetary policy can influence $P_{t}^{-1} \lim _{N \rightarrow \infty} I_{t+1, N}(1+$ $\left.i^{M}\right) M_{N-1}$. For this to be possible, the government must be able to change, through the issuance of money, the present discounted value of current and future taxes. Because of debt neutrality, when the government continues to satisfy its solvency constraint, postponing taxes by borrowing does not affect their present discounted value. Postponing taxes by issuing money can affect

\footnotetext{
${ }^{3}$ In more general models, the marginal propensity to consume out of comprehensive wealth, which is $\frac{\rho}{1+\rho}$ in the model considered here, will be a function of current and future real and nominal interest rates as well.
} 
the present discounted value of current and future taxes if and only if this can influence $P_{t}^{-1} \lim _{N \rightarrow \infty} I_{t+1, N}\left(1+i^{M}\right) M_{N-1}$. Because of debt neutrality, a helicopter drop of money in period $t$, financed by a period $t$ tax cut (the benchmark) has the same effect as one financed by the purchase of bonds in period $t$, with taxes in period $t+1$ and/or later cut by the same amount in present value as the period $t$ tax cut in the benchmark. Helicopter drops of money and open market purchases are equivalent when the government satisfies its solvency constraint identically in both scenarios.

The equilibrium behaviour of the stock of real money balances under a constant growth rate of the nominal stock of money (equation (16)) is given by

$$
m_{t+1}=\frac{(1+\rho)(1+v)}{1+i^{M}}\left(m_{t}-\frac{1-\alpha}{\alpha}\left(y^{*}-g\right)\right), \quad 1+v \geq\left(1+i^{M}\right)(1+\rho)^{-1}
$$

This has two steady state equilibria, the barter equilibrium $\bar{m}=0$, which will be considered no further and

$$
\overline{\bar{m}}=\frac{1-\alpha}{\alpha}\left(\frac{(1+\rho)(1+v)}{(1+\rho)(1+v)-\left(1+i^{M}\right)}\right)\left(y^{*}-g\right)
$$

When $1+v>\left(1+i^{M}\right)(1+\rho)^{-1}$, the steady state $(35)$ is unstable. Any initial value of the real money stock below $\stackrel{\bar{m}}{\bar{m}}$ cannot be part of an equilibrium sequence because the real stock of money balances would become negative (inflationary bubbles are therefore ruled out). Any initial value of the real

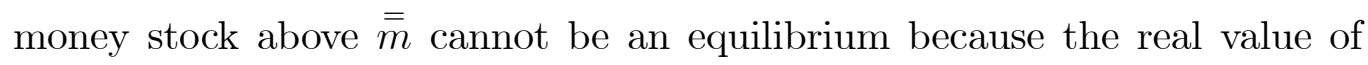


the stock of money balances would increase without bound. Its proportional growth rate would in the long run converge to $\frac{(1+\rho)(1+v)}{1+i^{M}}-1$ and the nominal interest rate to $i^{M}$. With the real interest rate equal to $\rho$, the present value of the terminal stock of real money balances would grow without bound. From the consumption function in (33), this would violate the economy-wide real resource constraint.

Thus the only equilibrium (other than the barter equilibrium) is the stationary equilibrium (34). The result, which can be found in Buiter and Sibert [12] for more general utility functions, that deflationary bubbles don't exist, even when the government issues both money and bonds, is new and depends crucially on the assumption that money is irredeemable. Without that, deflationary bubbles would exist if the government issues both monetary and non-monetary liabilities and has an appropriate FFMP, such as the one given in equations (16), (20) and (18) (see Woodford [50]). Since our tax rule keeps constant the real value of money plus bonds - the only state variable in the household's optimisation programme - the unbounded increase in the real value of the stock of money would be balanced by an unbounded increase in the negative value of the real non-monetary debt. This is no longer true when money is irredeemable and the term $P_{t}^{-1} \lim _{N \rightarrow \infty} I_{t+1, N}\left(1+i^{M}\right) M_{N-1}$ is present in the consumption function $(33) .{ }^{4}$

Definition 1 A liquidity trap is an equilibrium in which all current and future short nominal interest rates are at their lower bounds, that is, an

\footnotetext{
${ }^{4}$ An equivalent statement of the non-existence of a deflationary bubbles equilibrium can be made by showing how this would cause the transversality condition ( 7$)$ to hold only if $u_{c}=0$, which would violate the economy-wide real resource constraint $c+g \leq y^{*}$.
} 
economy is in a liquidity trap at time $t_{0} \geq 1$, if $i_{t}=i_{t}^{M}, t \geq t_{0}{ }^{5}$

This is a rather more restrictive definition than is used by Svensson in [43]. His definition of a liquidity trap only requires that the current short nominal rate be at its lower bound. It is therefore not surprising, that Svensson's 'foolproof' method for avoiding liquidity traps or escaping from them, does not work when the economy is stuck in the rather more severe liquidity trap considered here.

When $1+v=\left(1+i^{M}\right)(1+\rho)^{-1}$ the unique non-barter stationary equilibrium is Friedman's optimum quantity of money (OQM) equilibrium, with $i_{t}=i^{M}$ and $1+\pi_{t}=1+v$. With the log-linear period felicity function in (9), the stock of real money balances goes to infinity when $i$ approaches $i^{M}$, as is apparent from (24). This is awkward but does not affect the argument about how the weak real balance effect associated with the irredeemability of money rules out deflationary bubbles and indeed all liquidity trap equilibria other than Friedman's OQM steady state.

In equilibrium, the consumption function (33) becomes

$$
c_{t}=y^{*}-g+\frac{\rho}{1+\rho} P_{t}^{-1} \lim _{N \rightarrow \infty} I_{t+1, N}\left(1+i^{M}\right) M_{N-1}, t \geq 1
$$

Together with the commodity market equilibrium condition (22), (36)

\footnotetext{
${ }^{5}$ If there were longer maturity nominal bonds, the definition of a liquidity trap would require that the risk-free nominal interest rates on bonds of all maturities be at their lower bounds. In the simple formal model of this paper, with has no uncertainty, longermaturity rates can be derived from current and (anticipated) future short nominal rates through the expectations hypothesis.
} 
implies that, for an equilibrium to exist, it must be the case that

$$
P_{t}^{-1} \lim _{N \rightarrow \infty} I_{t+1, N}\left(1+i^{M}\right) M_{N-1}=0, t \geq 1
$$

Condition (37) suggest some simple characteristics that a monetary rule should have to rule out liquidity trap equilibria other than Friedman's OQM equilibrium. Consider the following rule:

$$
\begin{aligned}
1+v & =\frac{1+i^{M}}{1+\rho} \text { if } \pi_{t+1}=\pi_{t} \\
& \geq 1+i^{M} \text { otherwise. }
\end{aligned}
$$

The first part of the monetary rule, (38), supports Friedman's stationary OQM equilibrium. The second part, (39), ensures no other liquidity trap equilibrium exists. This is most easily shown by assuming the contrary. If a liquidity trap equilibrium exists, starting in period $t_{0} \geq 1$, then $\frac{1}{P_{t}} \lim _{N \rightarrow \infty} I_{t+1, N}\left(1+i^{M}\right) M_{N-1}=\frac{1}{P_{t}} \lim _{N \rightarrow \infty}\left(1+i^{M}\right)^{-(N-1)} M_{N-1}=$ $\frac{1}{P_{t}} \lim _{N \rightarrow \infty}\left(\frac{1+v}{1+i^{M}}\right)^{N-1} M_{0}=(1+\nu)^{-t} \frac{M_{t}}{P_{t}} \lim _{N \rightarrow \infty}\left(\frac{1+v}{1+i^{M}}\right)^{N-1}$ for all $t \geq t_{0}$. With $v \geq i^{M},(1+\nu)^{-t} \frac{M_{t}}{P_{t}} \lim _{N \rightarrow \infty}\left(\frac{1+v}{1+i^{M}}\right)^{N-1}=0$ only if $\frac{M_{t}}{P_{t}}=0$. Since by assumption $i_{t}=i^{M}$, it follows that $\frac{M_{t}}{P_{t}}=+\infty>0 .{ }^{6}$

In the conventional benchmark $\left(i^{M}=0\right)$ it follows that liquidity trap equilibria are ruled out as long as the authorities are believed not to demonetise the economy (reduce the undiscounted nominal stock of base money

\footnotetext{
${ }^{6}$ All that is required is that the demand for real money balances is positive when the pecuniary opportunity cost of holding money is zero. An infinite demand for real money balances when $i=i^{M}$ is not necessary.
} 
to zero) in the long run. ${ }^{7}$ Essentially the same result holds when the economy has nominal price rigidities. The Phillips curve in equation (40) provides two examples. Output is demand-determined: $y=c+g$ and $\pi_{t} \equiv P_{t} / P_{t-1}$.

$$
\pi_{t+1}=\pi_{t}+\eta_{0}-\eta_{1}\left(y^{*}-y_{t}+\eta_{1} \eta_{0}^{-1}\right)^{-1}
$$

The New-Keynesian version has $\eta_{0}, \eta_{1}>0$. The price level $P$, is predetermined but the rate of inflation $\pi$ is not. Equation (40) solves for the current rate of inflation as an increasing function of current and (anticipated) future output gaps, plus the long-run rate of inflation. The Old-Keynesian version has $\eta_{0}, \eta_{1}<0$. Both the price level and the rate of inflation are predetermined. Equation (40) solves for the current inflation rate as an increasing function of past output gaps plus the initial rate of inflation. Under both interpretations, actual output cannot exceed a finite maximum level given by $\bar{y}=y^{*}+\eta_{1} \eta_{0}^{-1}$. A sufficiently large value for the undiscounted terminal stock of base money will rule out liquidity trap equilibria. Any growth rate of the nominal money stock higher than the interest rate on money is sufficient but not necessary for that. When the interest rate on money is zero, any positive growth rate of the nominal money stock will, if it is expected to be maintained in the long run, rule out liquidity trap equilibria.

It is the expected behaviour of the long-run stock of base money that matters. If despite a record by authorities of current and past positive growth of the nominal money stock, the private sector expects that, in the long run, any current and past money stock increases will be reversed, the economy

\footnotetext{
${ }^{7}$ In Friedman's OQM equilibrium, the nominal stock of money balances goes to zero in the long run when $i^{M}=0$.
} 
could be stuck on a liquidity trap solution trajectory for as long as these incorrect but irrefutable expectations persist. ${ }^{8}$

\section{Negative nominal interest rates}

Why did we not see negative nominal interest rates in Japan during the years 2000-2003? The short answer is that the risk-free short nominal interest rate on non-monetary financial instruments (nominal bonds) is bounded from below by the nominal interest rate on base money. Since currency has a zero nominal interest rate, the nominal interest rate on bonds cannot be negative. The slightly longer answer is that base money consists of currency and commercial bank reserves with the central bank. Let the nominal interest rate on currency be $i^{C}$, the nominal interest rate on bank reserves $i^{R}$, the carry cost of bonds $\gamma$, the carry cost of currency $\gamma^{C}$ and the carry cost of bank reserves $\gamma^{R}$ If both currency and base money have superior liquidity to bonds, the following equality must hold: ${ }^{9}$

$$
i-\gamma \geq \operatorname{Max}\left\{i^{C}-\gamma^{C}, i^{R}-\gamma^{R}\right\}
$$

The storage and security costs of holding currency in large amounts are high, so $\gamma^{C}>\gamma \approx \gamma^{R} \approx 0$. The nominal interest rate on bank reserves with the central bank can be anything, positive or negative. These are balances

\footnotetext{
${ }^{8}$ The expectations are irrefutable because they relate to the behaviour of the nominal money stock in the infinitely distant future. The expression incorrect but irrefutable (IBI) expectations is due to Anne Sibert.

${ }^{9} i^{C}$ reprsents the pecuniary returns on currency to honest folk. The criminal uses of currency bestow on it an often much higher risk-adjusted expected rate of return than is available (for the criminal) on less anonymous investments with higher conventional pecuniary rates of return.
} 
in electronic ledgers. The creditor (the central bank) knows exactly the size of the balances held at each instant by the debtors (the commercial banks). When you know the legal identity of the owner and how much he holds at each instant, paying interest, positive or negative, is trivially simple. The binding constraint on the nominal interest rate is therefore the interest rate on currency, net of carry costs:

$$
i \geq i^{C}-\gamma^{C}
$$

Since the interest rate on currency is zero, the interest rate on bonds can only be negative by the margin permitted by the (high) carry costs of currency. That may not be enough for monetary policy purposes during a sharply deflationary episode.

The reason currency does not pay interest, positive or negative, is that it is administratively costly so to do. Currency is a negotiable bearer bond. The holder (owner) is anonymous. Because the issuer does not know the identity of the bearer, it must be possible to identify for each particular unit of the monetary instrument (currency notes) whether interest due has been paid or received. This is necessary both to prevent a given note from being presented repeatedly for the payment of (positive) interest or to induce the anonymous owner to come forward and pay any interest due to the issuer (in the case of negative interest). Notes have to be stamped or marked, the way old-fashioned positive interest-bearing bearer bonds coupons were clipped when interest was paid. The idea of taxing currency in this way goes back at least to Gesell [22], was supported by Irving Fisher [18] and has 
recently been revived by Buiter and Panigirtzoglou [10], [11] and Goodfriend $[23]$.

There is no doubt that imposing a carry tax on currency would be administratively cumbersome - it would require, for instance, sufficiently heavy penalties for using unstamped, interest-overdue currency to induce holders of currency to come forward and pay the tax. These costs have to be set against the cost of being stuck at the zero bound or the cost of pursuing policies that would make it unlikely that the zero bound could become a binding constraint - a higher (target) rate of inflation. ${ }^{10}$

\section{The fallacy of the Fiscal Theory of the Price Level}

The main theme of this lecture is that monetary policy is part of intertemporal public finance. However, not every theory asserting a strong link between the government budget and the price level makes sense, as is evident from the rise and fall of the so-called "Fiscal Theory of the Price level", a theory first proposed in the 1980s (see Begg and Haque [4]), which gained prominence during the 1990s (see Sims [39], [40], [41], [42], Woodford [45], [46], [47], [48], [49], [50], Cochrane [13], [14], [15] and Kocherlakota, Narayana and Phelan [27]). The FTPL was shown to be a fallacy in Buiter [7] and Niepelt [32] (see also McCallum [29], and Benassy [5]). The key assumption of the FTPL is that, when the nominal interest rate is set exogenously (or as a function of

\footnotetext{
${ }^{10}$ If the zero nominal interest rate on currency were really the only obstacle to setting negative nominal interest rates, that would represent a powerful motive for getting rid of currency completely (see also Section 6).
} 
real variables only), the GIBC does not have to hold identically but only in equilibrium. This assumption is unacceptable because it denies the single most important defining characteristic of a market economy: hard budget constraints based on clearly defined property rights, backed up with default penalties in case of non-observance. Not surprisingly, the FTPL, a theory based on turning an identity into an equilibrium condition, has a large number of anomalous and inconsistent implications. A theory is only as good as the sum total of its implications. That makes the FTPL a spectacular monetary theory erratum and corrigendum.

In the eight Subsections of Section 5 that follow, I outline a few of the more notable anomalies and inconsistencies implied by the FTPL. Before turning to these, however, it is important to bring out the intrinsic enormity of confusing the roles of equilibrium conditions and identities in general equilibrium models, including the dynamic monetary general equilibrium models under consideration here.

The budget constraint is a fundamental building block of any market economy. It is the requirement that an agent's financial plan be internally consistent or coherent: the sum of all planned uses of funds should not exceed the sum of all planned or expected sources of funds. In dynamic macroeconomic models, two kinds of uses and sources of funds can be distinguished: contractual and discretionary. Contractual uses (sources) of funds in any period $t$ are predetermined payments to be made (received) on financial instruments inherited from period $t-1$. Failure to meet such contractual obligations in the case of a debtor mean default and possible bankruptcy, intervention by the courts and legal or other sanctions. Discretionary uses and sources of 
funds are payments and receipts that can be freely chosen in period $t+1$. Period $t$ private and public consumption, endowments, taxes and purchases or sales of financial instruments fall into that category. The budget constraint of an agent implies that not all discretionary uses and sources of funds can be specified independently if he is committed always to fulfill his contractual financial obligations. It also implies that, if all discretionary uses and sources of funds are specified independently (without regard to his outstanding contractual obligations), the economic agent will not, in general, be able to meet his outstanding contractual financial obligations. The budget constraint then implies that if the agent sticks to (implements) his plan for all discretionary uses and sources of funds, the outstanding (predetermined) contractual financial obligations will have to be overwritten and revalued (or re-priced) for the planned discretionary uses and sources of funds to be feasible.

A familiar example is non-performing debt which is priced at a discount from its notional value because the present value of current and future expected debt service is less that the debt's notional or contractual value. The CTPL asserts that the budget constraint applies in the same way to all economic agents. It applies when the agent is small (say, a price-taking consumer or competitive firm) or large (say a monopolist or a government that recognises its market power). It applies to the private sector and to the government. The government has some unique sources of funds at its disposal: it has to power to tax (which is a legal monopoly) and the ability to assert a monopoly over the issuance of negotiable bearer notes (cash) and to attach special privileges (such as legal tender status) to that financial instrument. However, even a large economic agent with two unique sources of 
funds is subject to the requirement that the sum of all planned discretionary uses of funds cannot exceed the sum of all expected discretionary sources of funds, if outstanding contractual commitments are to be met.

The CTPL allows for the possibility that the government may not be able to, and may not even plan to, meet its contractual debt obligations. An overdetermined FFMP is possible. An example is the Non-Ricardian tax policy where (19) holds instead of (18): real spending and real taxes plus seiniorage are specified exogenously for all time, without any reference to the government's outstanding stock of debt obligations. In that case, from the perspective of the CTPL, (20) no longer applies, the budget constraint becomes 'soft', and $V_{t} f_{t}$ becomes an endogenous variable, revaluing the government's outstanding contractual obligations to bring consistency to the FFMP. The government 's intertemporal budget constraint becomes an effective real public debt pricing kernel. ${ }^{11}$

The interpretation of $V_{t}<0$ and $f_{t}>0$ is that the government imposes, at the very beginning of period $t$, a capital levy (not included in $\bar{\tau}$ ) which allows it to pay off the outstanding contractual public debt and have some resources left to achieve a net credit position vis à vis the private sector. ${ }^{12}$ If this argument does not convince, we must conclude that, if the GIBC with

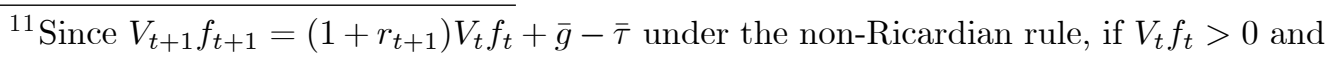
$\bar{g}-\bar{\tau}>0$, the growth rate of the effective real debt would exceed the real interest rate each period. The governments solvency constraint (12) would be violated. If $V_{t} f_{t}<0$ and $\bar{g}-\bar{\tau}<0$, the growth rate of the real effective stock of government net non-monetary credit would exceed the real interest rate each period, so in equilibrium the household's solvency constraint (3) would be violated. However, if we permit $V_{t}<0$, then $\operatorname{sgn}\left\{V_{t} f_{t}\right\}=\operatorname{sgn}$ $\{\bar{\tau}-\bar{g}\}$ says nothing about the relationship between $\operatorname{sgn}\left\{f_{t}\right\}$ and $\operatorname{sgn}\{\bar{\tau}-\bar{g}\}$.

${ }^{12}$ The interpretation of $V_{t}<0$ and $f_{t}<0$ is that the contractualy net creditor government makes, at the very beginning of period $t$, a capital transfer (or gift) (again not included in $\bar{\tau}$ ) which allows the private sector to pay off its outstanding contractual debt to the government and have some resources left to extend net credit to the public sector.
} 
the non-Ricardian fiscal rule and the overdetermined FFMP can be satisfied only with a negative value of $V_{t}$, then no equilibrium exists.

Whether a positive value of $V_{t}$ greater than one is acceptable, depends on how far one is willing to push the view that government debt is equity in the stream of current and future primary surpluses and seigniorage. The conventional view is that debt is equity without the upside: debt may sell for less than its contractual value, but it cannot sell for more: $0 \leq V_{t} \leq 1$. If public debt is viewed as true equity, with an upside as well as a downside, $V_{t}>1$ would be acceptable. When $f_{t}>0, V_{t}>1$ can be interpreted as an extraordinary dividend paid to the private bond holders. If we insist on $V_{t} \leq 1$ but the solution for $V_{t}$ from the GIBC gives $V_{t}>1$, we must find some other way to determine how the government disposes of the excess of the present value of its current and future primary surpluses plus seigniorage over the contractual value of its outstanding debt. Otherwise no equilibrium exists in this case either. This is an open issue.

The FTPL asserts that it is possible to have an overdetermined FFMP (e.g. the Non-Ricardian tax rule in (19)) but still to require that the government meets its financial obligations exactly, that is, (20) holds. What makes this possible, according to the FTPL, is that the general price level $P_{t}$ plays the role played by $V_{t} f_{t}$ in the CTPL. In my simple model, the period $t$ GIBC alone determines the general price level. 


\subsection{I could not have started from here}

Niepelt [32] makes the point that the combination of a non-zero predetermined, outstanding stock of nominal government debt and a non-Ricardian FFMP could not be the outcome of an equilibrium process. How did the household that holds $B_{t-1}$ at the beginning of period $t$ come to choose that stock of nominal contractual debt obligations in earlier periods? In a rational expectations equilibrium a household's willingness to take on nominal debt in period $t-1$ is contingent on that debt earning the appropriate (risk-adjusted) real rate of return between periods $t-1$ and $t$. In our simple model, this is reflected in the condition that $1+r_{t+1}=\left(1+i_{t+1}\right) \frac{P_{t+1}}{P_{t}}$ for all $t \geq 1$.

The FTPL determines the initial value of the general price level from equation (43) for $t=1$ :

$$
\left(\frac{\left(1+i_{t}\right) B_{t-1}}{P_{t}}+\left(1+r_{t}\right) d_{t-1}\right)=\frac{1+\rho}{\rho}(\bar{\tau}-g) .
$$

Niepelt asserts that we cannot simply assume that in the initial period, $t=1$, there is a positive stock of nominal government bonds outstanding, $B_{0}>$ $0 .{ }^{13}$ We have to be able to explain the initial stock of government nominal debt outstanding an equilibrium outcome with rational private saving and investment behaviour in periods before the initial period.

What this argument amounts to is that,in some 'pre-initial period', period 0, say, there was zero nominal government debt outstanding, so the GIBC for that period was

\footnotetext{
${ }^{13}$ Assuming that $\left(\frac{1+\rho}{\rho}\right)(\bar{\tau}-g)-\left(1+r_{1}\right) d_{0}>0$.
} 


$$
\left(1+\bar{r}_{0}\right) \bar{d}_{-1}=\frac{1+\rho}{\rho}(\bar{\tau}-g)
$$

It is clear that, since both sides of equation (44) are exogenously determined, the FTPL will, generically, produce an overdetermined equilibrium. The CTPL, of course, keeps going strong also in this case. Its counterpart to equation (44) is

$$
V_{0}\left(1+\bar{r}_{0}\right) \bar{d}_{-1}=\frac{1+\rho}{\rho}(\bar{\tau}-g) .
$$

With an overdetermined non-Ricardian fiscal rule, the government will not, in general, be able to meet its contractual obligations exactly: $V_{0} \neq 1$. The GIBC now determines the effective real value of the non-monetary public debt $V_{0}\left(1+\bar{r}_{0}\right) \bar{d}_{-1}$ through the endogeneity of the public debt revaluation factor $V_{0}$.

Niepels is correct that government fiscal policies must be Ricardian if the initial stock of nominal government debt is to be rationalisable as the outcome of a rational expectations equilibrium. I do not share his view that the initial stock of nominal government debt ought always to be rationalised this way. I am happy to take the inherited stock of contractual obligations to be whatever it is - history happened. There are then two ways for the government to deal with its inherited contractual obligations - and it is irrelevant whether these are nominal or real. Either government fiscal policies are Ricardian or the non-monetary government debt (real and/or nominal) is revalued, through an endogenous public debt revaluation factor, $V_{t}$ to ensure that the effective real value of the government's debt in each period $V_{t} f_{t}$ 
satisfies the GIBC for that period.

When the authorities fix the nominal interest rate sequence exogenously, the CTPL has nominal indeterminacy, both with the Ricardian and the nonRicardian fiscal rule. All real variables - the real stock of money balances, the inflation rate, the nominal interest rate and the effective real value of the government's non-monetary debt $\left(V_{t} f_{t}\right.$ in the non-Ricardian case) are uniquely determined, but the nominal money stock and the general price level are indeterminate. In the non-Ricardian case, if $B_{t} \neq 0$, neither the general price level $P_{t}$ nor the public debt valuation factor $V_{t}$ are determinate, although the variable that matters, $V_{t} f_{t}$, is uniquely determined as the real 'residual claim' to the future primary surpluses and seigniorage of the state. The nominal indeterminacy of the conventional model is not a problem or a weakness. It is simply a reflection of the fact that the authorities have not provided a nominal anchor for the system. ${ }^{14}$

Superficially, the presence of a positive outstanding stock of non-monetary nominal public debt plus the assumption that the authorities peg the nominal interest rate may appear to provide an escape from the real overdeterminacy that would normally be expected under an (overdetermined) non-Ricardian fiscal rule when the government is required to honour its contractual obligations. Closer inspection of the putative FTPL equilibrium and its properties demonstrates, however, that anomalies and contradictions abound. I will list a few of the most interesting ones.

\footnotetext{
${ }^{14}$ The nominal interest rate (more precisely, the difference between the nominal interest rate and the nominal interest rate on base money), is a real variable - the real pecuniary rate of return differential between money and bonds.
} 


\subsection{Prices clear markets, not budget constraints}

Economists think of equilibrium prices as clearing markets, not budget constraints. Also, a particular equilibrium is viewed as more interesting and relevant, if it can be shown to be the outcome of an equilibrating process that drives prices back to the equilibrium when the equilibrium is perturbed. Ideally, the 'out-of-equilibrium' forces driving prices back to equilibrium would themselves be modeled as part of some more general 'meta-equilibrium model', but the complexity of such an approach is such that Walrasian or Marshallian tâtonnement-type adjustment processes taking place in virtual time rather than calendar time are often resorted to. ${ }^{15}$ Walrasian tâtonnement, for instance, has a price rising if, at the prevailing level of that price, there is excess demand. What plausible disequilibrium adjustment story can one tell if the value of the general price level in period 1 , say, is below the value that equates both sides of the GIBC in equation ([?]) for $t=1$ ? Why would there be any upward pressure on the general price level in period 1 , simply because at the prevailing value of $P_{1}$ the real value of the government's non-monetary debt exceeds the present discounted value of current and future real primary surpluses plus real seigniorage? This critique of the FTPL, due to John Sutton, is similar in spirit, although quite different formally, from McCallum's demonstration that the FTPL is not 'learnable' (see McCallum [31]).

\footnotetext{
${ }^{15}$ Walrasian tâtonnement has a price rising (falling) when there is excess demand (supply) at the current price. Marshallian tâtonnement has a quantity rising (falling) when the damand price exceeds (is below) the supply price
} 


\subsection{The HTPL and the ETPL}

As regards the valuation of its debt, the government is in a position that is not fundamentallydifferent from that of any private agent. The conventional household optimisation problem solved in Section 2.1 assumes that the HIBC holds identically (that is, the household follows a 'Ricardian consumption plan'). Instead, we could, by analogy with the FTPL, have any individual household (or, perhaps a set of households with market power) fix every element in their infinite sequences of real consumption $\left\{c_{t} ; t \geq 1\right\}$ and consumption of real liquidity services $\left\{m_{t}\left(\frac{i_{t+1}-i_{t+1}^{M}}{1+i_{t+1}}\right) ; t \geq 1\right\} .{ }^{16}$ The HIBC, treated as an equilibrium condition rather than an identity, would then be turned into a household real debt revaluation equation or household real debt pricing kernel. If we then insist that the household meet its contractual debt obligations exactly, we would have the HIBC theory of the price level or HTPL. In models with private enterprises as well as households, we could do the same for any enterprise with monopoly power and have the enterprise budget constraint theory of the price level or ETPL. This would be nonsense, of course, just like the FTPL.

\subsection{The FTPL when the money stock is exogenous: sometimes I feel like an identity, sometimes I don't}

Problems of overdeterminacy are present when the government fixes the sequence of nominal money stocks, as in equation (16). With the non-

\footnotetext{
${ }^{16} \mathrm{An}$ alternative would be to fix only one element of the infinite consumption sequence and to use the first-order conditions for a household optimum to derive the others and the sequence of real money balances.
} 
Ricardian FFMP and $V_{t}=1, t \geq 1$, the period $t$ price level is determined from the period $t$ GIBC in equation (43) alone.

Stepping away from our log-linear utility function, consider the case where the demand for real money balances is independent of the nominal interest rate, say, because it is derived from a simple Lucas-Stokey cash-in-advance constraint:

$$
\begin{aligned}
M_{t} & \geq P_{t} c_{t} \\
& =P_{t} c_{t} \text { if } i_{t}>i_{t}^{M}
\end{aligned}
$$

Assume the growth rate of the nominal money stock is sufficiently high to ensure that $i_{t}>i^{M}$, for all $t \geq 1$ (this requires $1+v>\frac{1+i^{M}}{1+\rho}$ ). In that case $P_{t}=\frac{M_{t}}{y^{*}-g}, t \geq 1$. The price level is over-determined. When the demand for money is sensitive to the nominal interest rate, there is overdeterminacy of the price level when the economy lasts for a finite number of periods (see Buiter [7]). With an infinite horizon, there is non-existence of equilibrium. This follows from the analysis of inflationary and deflationary bubbles in Section 3. There can be an equilibrium only if the initial price level determined by the GIBC happens to support the stationary state solution to (34) given in (35). More general utility functions may weaken this stark non-existence result somewhat.

The response of proponents of the FTPL to the overdeterminacy problem when the government sets an exogenous nominal money stock sequence rather than an exogenous nominal interest rate sequence, is that the FTPL 
was never meant to apply to the case where the nominal money stock is exogenous. When $M$ is the exogenous instrument, the budget constraint should hold identically and the fiscal rule should be Ricardian.

But why should the details of the monetary rule determine whether the government views its intertemporal budget constraint as an identity rather than an equilibrium condition? If the government were to set the nominal interest rate not exogenously but as a function of the nominal money stock (or any other nominal variable), say $i_{t}=\beta_{1}+\beta_{2} M_{t}, \beta_{2} \neq 0$, the GIBC would have to be an equilibrium condition rather than identity. If it were to set the nominal interest rate as a function of the real money stock (or any real variable), say $i_{t}=\beta_{1}^{\prime}+\beta_{2}^{\prime} m_{t}$, the GIBC could be an equilibrium condition and the fiscal rule could be non-Ricardian. This flip-flopping of the GIBC from being treated as an identity to being treated as an equilibrium condition, with no justification other than that this makers the number of equilibrium conditions equal the number of unknowns, is unacceptable methodologically. Restrictions on individual behavioural relationships should not be based on system-wide or general-equilibrium considerations.

\subsection{A negative price level, anyone?}

Consider the nominal interest rate rule (17) for which, under the CTPL, that is, in well-posed general equilibrium models, there always is, and should be, nominal indeterminacy. The FTPL enrols the period $t$ general price level, $P_{t}$, for the part played in well-posed monetary general equilibrium models by $V_{t} f_{t}$. The GIBC determination of the price level makes sense only if the 
implied price level is non-negative. That is, the following relationship must hold:

$$
\operatorname{sgn}\left\{\frac{\left(1+i_{t}\right) B_{t-1}}{P_{t}}\right\} \equiv \operatorname{sgn}\left\{\frac{1+\rho}{\rho}(\bar{\tau}-\bar{g})-\left(1+r_{t}\right) d_{t-1}\right\}, t \geq 1
$$

In period 1 , all variables in (46) other than $P_{1}$ are either predetermined or exogenous. If all debt were nominal debt, that is, $\left(1+i_{1}\right) \frac{B_{0}}{P_{1}}=f_{1}$, the violation of (46) would imply that either the government's or the private sector's solvency constraint is violated. ${ }^{17}$ However, if $d_{t} \neq 0$, we cannot use this argument to argue that (46) will be satisfied whenever the solvency constraints are satisfied, We can have $\operatorname{sgn}\left\{f_{t}\right\}=\operatorname{sgn}(\bar{\tau}-\bar{g})$, which is consistent with government solvency, yet have $\operatorname{sgn}\left\{\frac{\left(1+i_{t}\right) B_{t-1}}{P_{t}}\right\} \equiv \operatorname{sgn}\left\{f_{t}-\left(1+r_{t}\right) d_{t-1}\right\} \neq$ $\operatorname{sgn}\{(\bar{\tau}-\bar{g})\}$.

\subsection{Pricing phlogiston}

A startling implication of the FTPL is that it can price the numeraire, even if the numeraire has no existence (not even a completely disembodied existence) as a good, service or pure financial claim. Pricing something that lives a binary, disembodied existence in cyberspace need not be a problem. However, the FTPL can price a pure numeraire: equation (43) can (sub-

\footnotetext{
${ }^{17}$ Since $f_{t+1} \equiv\left(1+r_{t+1}\right) f_{t}+g_{t}-\tau_{t}-s_{t}=\left(1+r_{t+1}\right) f_{t}+\bar{g}-\bar{\tau}$ under the non-Ricardian rule, if $f_{t}>0$ and $\bar{g}-\bar{\tau}>0$, the proportional growth rate of the debt would exceed the real interest rate each period, so the government solvency constraint (12) with $V_{t}=1$, would be violated. If $f_{t}<0$ and $\bar{g}-\bar{\tau}<0$, the proportional growth rate of the stock of government net non-monetary credit would exceed the real interest rate each period, so in equilibrium the household's solvency constraint (3) with $V_{t}=1$, would be violated.
} 
ject to (46)) price the numeraire, (whatever it is that $B_{t}$ is denominated in) even if money (in the sense of a transactions medium, medium of exchange, most liquid store of value or whatever) not only plays no unique role in the economy, but does not exist. In an earlier paper on the subject [7], I called this pure numeraire phlogiston, after the imaginary substance that, before the ascent of modern science, was believed to be responsible for combustion. Such a non-existing, purely imaginary substance makes a perfectly acceptable numeraire. Any two commodities priced in phlogiston will have a well-determined relative price. Determining the price of phlogiston itself when phlogiston does not exist except as a word, is an intellectual bridge too far (for a contrary view, see Cochrane [15]).

\subsection{No FTPL for Keynesians, New or Old}

The price level cannot be determined by the GIBC in the manner proposed by the FTPL, if the price level is predetermined, that is, inherited from the past, as it is in both Old-Keynesian and New-Keynesian models. Equation (40) provides an example of a New/Old - Keynesian Phillips curve with a pre-determined price level. The real interest rate need not be constant and equal to the time preference rate when output is demand-determined, so the overdeterminacy of the FTPL equilibrium when the price level is not instantaneously flexible cannot be determined just from the GIBC itself. Indeterminacy is, however, present. 


\subsection{Unpleasant monetarist arithmetic is not the FTPL}

One of the most important contributions of the past 40 years to monetary theory as a branch of intertemporal public finance has been the "Unpleasant Monetarist Arithmetic" (UMA) paper of Sargent and Wallace [35]. Needless to say, this paper is not an example of the FTPL at work but instead constitutes an elegant example of the CTPL. The UMA paper analyses a Ricardian FFMP with contract fulfillment $\left(V_{t}=1\right)$. There is only index-linked debt, so $B_{t}=0, t \geq 0$. Ignoring trend growth for simplicity, real public spending and real taxes are constant: $g_{t}=g, \tau_{t}=\tau, t \geq 1$. There is a regime switch in period $t_{1}>1$. From period 1 till period $t_{1}-1$, the authorities fix the growth rate of the nominal money stock at some exogenous level $v$. Index-linked public debt is issued or retired in whatever amount is required to satisfy the period budget identities of the government from period 1 till

$t_{1}$. In period $t_{1}$, the government stabilises the real stock of non-monetary public debt, that is, $d_{t}=d_{t_{1}}, t \geq t_{1}$. The growth rate of the nominal money stock for all periods $t \geq t_{1}$ adjusts endogenously to a constant value that just satisfies the GIBC. The UMA framework implies a fiscal theory of inflation: inflation is a monetary phenomenon, but monetary growth is, through the GIBC and the Ricardian FFMP, a budgetary or fiscal phenomenon.

\section{The vanishing monetary base}

There is no reason to believe that the financial instruments currently making up base money, currency and commercial bank balances with the central bank will be around forever, or even for very much longer (see e.g. [19] and [20]). 
The legal domestic uses of a currency are effectively confined to low value retail transactions. The poor, who tend not to have access to formal sector financial intermediaries, use currency disproportionately. The currencies of some major countries (especially the US dollar) are also used as stores of value and media of exchange in countries with unstable domestic currencies and histories of high or hyperinflation. An estimate by Federal Reserve Board staff suggests that "As much as two-thirds of all Federal Reserve notes in circulation -perhaps $\$ 250$ to $\$ 300$ billion are now held abroad" ([1], p.1; see also [16] , [33], [34] and [17]). Apart from this, the only significant demand for currency, especially for the larger denominations, comes from the grey, black and outright criminal sectors of the economy. The anonymity of the holder of currency - the same feature that makes it difficult to pay interest on currency - makes it attractive to all those engaged in criminal activity, from evading taxes on legitimately earned incomes or evading VAT for services provided by small contractors, to knowingly paying for criminally obtained goods and services, investing the proceeds from criminal activity and financing terrorism. ${ }^{18}$

There are increasingly attractive alternatives to currency for legitimate retail transactions, from centralised electronic means of payment like debit cards to decentralised ones like the 'cash on a chip' and other forms of $e$ money. In developed countries, the only domestic demand for currency will soon come just from the poor and from those engaged in illegal activity (in-

\footnotetext{
${ }^{18}$ In the US, no Federal Reserve notes with denominations over $\$ 100$ are issued, although there is still an oustanding stock of $\$ 500$ and $\$ 1000$ notes. It is regrettable, from a law enforcement point of view, that the ECB decided to issue $e 500$ notes, as there are few if any legitimate and legal uses for such large denomination notes.
} 
cluding terrorism). If a way can be found to enable the poor to have access to the convenience of e-money, there is an overwhelming law enforcement and national security case for doing away with legal tender currency issued by the state. Coins and small denomination currency notes could be exempted, for social and shopping convenience reasons. If the current prohibition on the private issuance of currency (negotiable bearer bank notes) were removed, we would probably see the re-emergence of private currencies, which flourished in the UK and the USA before the state granted itself a legal monopoly on negotiable bearer notes. Such private notes would still be popular means of payment and stores of value for the criminal community. From the perspective of law enforcement, an end to state-issued currency and the continuation of the ban on private negotiable bearer notes would have to be viewed as a package. An end to state-issued currency plus a continuation of the ban on private note issuance, enforced with appropriate sanctions, would therefore be preferable. Drehmann, Goodhart and Krueger [17] have argued "...that any attempt to force a complete shift to electronic transfer, and to try to ban, or to prevent, the domestic use of cash would be appallingly illiberal". ${ }^{19}$ If it were to be effective, that might be a price worth paying.

As regards commercial bank balances with the central bank, the details of the instrument should be distinguished from the services (the bundle of characteristics like liquidity and security) that the central bank provides to the commercial banks. Ignoring legally required reserves (a clumsy way of taxing deposit taking if the interest rate on the reserves is below the market rate), the demand for balances with the central bank derives from the unquestioned

\footnotetext{
${ }^{19}$ The quote is from the abstract of [17].
} 
liquidity of that instrument. Ultimately, that superior liquidity derives from the unquestioned security and creditworthiness of the central bank, as agent of the state. That security and creditworthiness derives partly from the legal tender nature of the central bank's monetary liabilities. More fundamentally, it derives from the fact that the central bank is an agent of the state, the sovereign, and that behind the central bank stand the Treasury with its power to tax and other government agencies with the power to regulate, that is, to prescribe and proscribe behaviour. The monopoly of the legitimate use of force (or coercion) is what makes the state unique. The central bank trades on that.

Assume both state-issued currency and banks' balances with the central bank have disappeared. The answer to the question: "will the state then lose control of short-term risk-free nominal interest rates?" is the same as to the question: "will the state cease to be more creditworthy than private agents?" That answer is 'no'. Clearly there are some states (mainly poor, highly indebted and encumbered with bad economic and political institutions) that are significantly less creditworthy than some very wealthy individuals and large and financially sound private enterprises. The ability to issue domestic base money at will is not very helpful when there is a shortage not of domestic liquidity but of foreign (hard) currency. There are also limits to the amount of domestic real resources that can be extracted through the issuance of base money especially when the capacity for inflicting inflation surprises on holders of base money and nominal government bonds is exhausted. The capacity to tax is subject to economic, administrative and political constraints. All this is true, yet it remains a fact that the creditworthiness of large and rich 
sovereign states is better than that of any private agent. ${ }^{20}$

The liquidity and security that the central bank as monetary agent of the state can provide through its liabilities is therefore unique - but there are many instrument(s) - existing or imagined - through which these two characteristics can be provided. A more efficient interbank market will deal effectively with the liquidity shortfalls of individual banks and other financial institutions. It cannot address a system-wide liquidity crunch. More efficient gross, net or mixed settlement systems, made possible by progress in highspeed digital computing and in other areas of ICT, including the use of intelligent artificial agents in settlement systems, will continue to increase the technical efficiency of private clearing, payment and settlement systems. But while the financial system has become more efficient, technically and economically in normal times, it has become more fragile and vulnerable in abnormal times - when buffeted by large adverse, systemic shocks.

The desirability of access to state (or state-backed) liquidity for key financial intermediaries will never go away. Deposits with the central bank may be replaced by overdraft facilities, lines of credit or other contingent claims on the resources of the central bank. The securities that provide the necessary liquidity may well turn out to be complex options that are off-balance sheet for both the central bank and the private intermediaries. Conventionally measured $M 0$ could be zero, yet there could be a sufficiently stable demand

\footnotetext{
${ }^{20}$ I share the view, expressed in McCallum ([30]), that the number of currencies is likely to continue to decline relative to the number of sovereign states. Many small sovereign nations have brittle and doubtful fiscal-financial viability. In addition, the economies of scale inherent in the provision of a stable currency with reliable and effective clearing and settlement systems will, in the not too distant future, leave room for at best a handful of viable currencies.
} 
for contingent credit claims on the central bank for the monetary authority to be able to set short term interest rates. ${ }^{21}$ Time will tell.

\section{What is an independent central bank inde- pendent of?}

I have almost come to the end of this lecture, but monetary and fiscal policy remain inextricably intertwined. There are no separate monetary, fiscal and public debt management authorities, just a 'government' that does it all. In practice, the consolidated monetary and fiscal authority of this lecture is broken down institutionally at least into a Central Bank and a Treasury, or Ministry of Finance. For simplicity, consider FFMPs with contract fulfillment only $\left(V_{t} \equiv 1, t \geq 1\right)$. Index-linked debt is also omitted, so $d_{t}=0, t \geq$ 1. In this closed economy, the central bank has the monetary base on the liability side of its financial balance sheet. On the asset side it has the stock of domestic credit which, for simplicity, is assumed to consist solely of central bank holdings of nominal Treasury bonds $B^{c b}$. As before, private sector holdings of Treasury debt are given by $B$. The real value of the tax

\footnotetext{
${ }^{21}$ The UK leads the way in shrinking the deposits with the central bank component of $M 0$. 'Cash ratio deposits' (reserve requirements) for deposit-taking institutions have been a mere $0.25 \%$ of eligible liabilities since 1998. The rationale for cash ratio deposits is seigniorage only. They serve no monetary policy function. Their existence is a classic example of a quasi-fiscal role of the central bank. Abolishing them and replacing them with an explicit tax or user charge on deposit-taking institutions would enhance transparency in the state budget.

In the UK, at the end of 2002, all of $M 0$ was 3.8 percent of 2002 GDP and the change in $M 0$ over the year was all of 0.21 percent of GDP. Under severe deflationary conditions, or during systemic liquidity crises, however, it is not the historical magnitudes of the stock of base money and of seigniorage that matter, but the ability of the monetary authorities to increase it, effectively instantaneously and costlessly, by any amount.
} 
payments by the private sector to the Treasury is $\tau^{p} ; \tau^{c b}$ is the real value of the payments made by the Central Bank to the Treasury, and $h$ is the real value of the transfer payments made by the Central Bank to the private sector ('helicopter drops'). Total taxes received by the state, that is, the consolidated Treasury and Central Bank are $\tau \equiv \tau^{p}-h$.

Equation (47) is the period budget identity of the Treasury and equation (48) that of the Central Bank. For notational simplicity, I assume that the Central Bank does not require any current expenditure.

$$
\begin{gathered}
B_{t}+B_{t}^{c b} \equiv\left(1+i_{t}\right)\left(B_{t-1}+B_{t-1}^{c b}\right)+P_{t}\left(g_{t}-\tau_{t}^{p}-\tau_{t}^{c b}\right) \\
M_{t}-B_{t}^{c b} \equiv\left(1+i_{t}^{M}\right) M_{t-1}-\left(1+i_{t}\right) B_{t-1}^{c b}+P_{t}\left(\tau_{t}^{c b}+h_{t}\right)
\end{gathered}
$$

The solvency constraint for the Treasury, $\lim _{N \rightarrow \infty} R_{t+1, N}\left(B_{N}+B_{N}^{c b}\right) / P_{N} \leq$ 0 and the solvency constraint for the Central Bank (incorporating the irredeemability of its monetary liabilities), $\lim _{N \rightarrow \infty} R_{t+1, N} B_{N}^{c b} / P_{N} \geq 0$, imply the following intertemporal budget constraints for the Treasury, equation (49) and for the Central Bank, equation (17)).

$$
\begin{gathered}
\frac{\left(1+i_{t}\right)\left(B_{t-1}+B_{t-1}^{c b}\right)}{P_{t}} \equiv \sum_{j=t}^{\infty} R_{t+1, j}\left[\tau_{j}^{p}+\tau_{j}^{c b}-g_{j}\right] \\
-\frac{\left(1+i_{t}\right) B_{t-1}^{c b}}{P_{t}} \equiv \sum_{j=t}^{\infty} R_{t+1, j}\left[-\tau_{j}^{c b}-h_{j}+\frac{M_{j}-\left(1+i_{j}^{M}\right) M_{j-1}}{P_{j}}\right]
\end{gathered}
$$

Typically, most or all of the equity of the Central Bank is owned by the 
Treasury. For instance, the Bank of England's own capital of $£ 14,553,000$ was transferred to HM Treasury in $1946 .^{22}$ The Treasury has a claim to all the profits of the Central Bank. We can represent this as in 51:

$$
\tau_{t}^{c b}=i_{t} \frac{B_{t-1}^{c b}}{P_{t}}-i_{t}^{M} \frac{M_{t-1}}{P_{t}}-h_{t}
$$

The financial relationship between the Central Bank and Treasury does not, de facto, include any form of limited liability. The Treasury stands ready to inject capital into the Central Bank's balance sheet, if this were deemed necessary for financial stability. Central Bank independence, whatever it means, must be consistent with complete financial dependence of the Central Bank on the Treasury (see [9]).

Can the Central Bank implement a helicopter drop of money on its own? It certainly can issue the money through an open market purchase of Treasury debt But it can only perform the other half of the operation, the tax cut or transfer payment to the private sector, if there is indeed something like $h$ in its arsenal. In practice, Central Banks do not act as fiscal agents of the state in this way. This means that Governor Mervyn King cannot send a $£ 1000$ check, drawn on the Bank of England, to every household in the nation. He

\footnotetext{
${ }^{22}$ The Federal Reserve System is an independent entity within the US Federal government. The stock of the twelve regional Federal Reserve Banks is owned by (private) member banks. Ownership of a certain amount of stock is, by law, a condition of membership in the System. The stock may not be sold or traded or pledged as security for a loan; dividends are, by law, 6 percent per year. The ECB is owned by the national central banks (NCBs) that make up the EU's European System of Central Banks (ESCB). The NCB's themselves have a variety of formal ownership structures, but their balance sheets and profit and loss accounts all are effectively integral parts of the consolidated financial accounts of the nation state to which they belong. The Bank of Japan's capital is one hundred million yen, subscribed by both the government and non-governmental persons, in exchange for subscription certifications (shares), with the government providing no less than 55 million yen
} 
needs Chancellor Gordon Brown's help. Gordon Brown can implement the tax cut and borrow from the Bank of England to finance it. In the Eurozone, direct borrowing by national Treasuries from the ECB and the ESCB is not permitted, but the same effect can be achieved by the Treasury borrowing in the market and the Central Bank purchasing the same amount of Treasury debt in the secondary market.

The uniquely effective demand-stimulating policy measure of a helicopter drop of money can therefore only be implemented if the Central Bank and the Treasury cooperate. For an independent Central Bank to be effective, there must be good communication, cooperation and coordination with the Treasury.

Independence is not a concept that fits comfortably in the conventional economic paradigm. In the 'real world', that is outside economics, 'independence' means that no-one can force you to do something you don't want to do. In economics we think of behaviour as being the outcome of the confrontation of objectives and constraints

The natural approach of an economist to the relationship between Central Bank and Government is to view it as a Principal-Agent problem. The Principal (the government, through the Treasury) delegates a task (determining the value of the short nominal interest rate) to an Agent (the Central Bank). Why such delegation occurs is an interesting issue in its own right, which will be addressed briefly below. The objectives of the Agent may not be congruous with those of the Principal. While the action of the Agent (the value of the short nominal interest rate) is observable and verifiable, the Agent has private information about his own objectives and about the relation- 
ship between the instrument, his own objectives and those of the Principal. By making an effort, the Agent can be more effective in the pursuit of the Principal's objectives. The Agent dislikes making an effort.

This standard Principal-Agent approach does not, however, capture some key features of the relationship between the Central Bank and the Treasury. First, the Central Bank is an Agent that takes decisions by Committee. Sibert [36], [37] has shown that the details of the rules and procedures of the Committee matter greatly for the outcome of its deliberations (see also Sibert and Mihov [38]). Second, the Treasury, while in the position of Principal visa-vis the Central Bank, is itself an Agent for a multitude of Principals - the electorate in a political democracy. ${ }^{23}$

In order to provide the right incentives to the Agent (the Central Bank) to pursue the objectives of the Principal (henceforth the official objectives), it must be possible for the Principal to monitor the performance of the Agent in with reference to both the ultimate official objectives (which may not be directly observable) and the operational or proximate official objectives. In the UK, both the ultimate official target (price stability) and the operational official target (the symmetric 2 percent per annum CPI inflation target) of monetary policy are set by the Principal. ${ }^{24}$ The ECB has complemented its non-operational official ultimate target - price stability - with at least one and possibly two operational targets set by its own Governing Council - the annual HICP inflation rate is to be 'close to but no higher than' two percent, and there is a 'monitoring range' for the growth rate of a broad

\footnotetext{
${ }^{23}$ The government itself is a collection of individuals and Committees.

${ }^{24}$ The CPI used to be called the Harmonised Index of Consumer Prices, or HIPC.
} 
monetary aggregate, M3. Things are even more opaque in the US, where the ultimate objectives of the Fed, laid down in the Federal Reserve Act ${ }^{25}$ are maximum employment, stable prices, and moderate long-term interest rates; there are no operational targets (other than the level of the Federal Funds rate itself). Accountability cannot exist without a verifiable criterion for measuring performance.

What are the private objectives of the members of the monetary policy making committees of the Central Bank and how do they influence the conduct of monetary policy? It is possible, but not likely, that all monetary policy makers fully internalise the official ultimate and operational targets set by the Principal and pursue them to best of their ability. If this is true, it would represent a highly unusual outbreak of Platonic Guardians Syndrome. A positive, political economy or public choice-type analysis of the making of monetary policy is both intellectually important and practically useful for the design of rules and incentives for monetary policy makers that optimise the monetary policy making process from the point of view of the ultimate Principals - the citizens of the polity.

It is difficult to come up with a convincing rationale for delegating monetary policy to a specialised agency of the state with a measure of operational independence without appealing to some form of bounded rationality. The argument that monetary policy is a technical issue requiring expertise be-

\footnotetext{
25 "The Board of Governors of the Federal Reserve System and the Federal Open Market Committee shall maintain long run growth of the monetary and credit aggregates commensurate with the economy's long run potential to increase production, so as to promote effectively the goals of maximum employment, stable prices, and moderate long-term interest rates." Federal Reserve Act, Section 2A-Monetary Policy Objectives.
} 
yond the ken of the Treasury is one example. So is the argument that the Chancellor of the Exchequer/Minister of Finance is simply to busy with nonmonetary fiscal policy issues to be able to cope with the additional demands of monetary management.

One common argument for an operationally independent Central Bank that does not rely on bounded rationality is that this is a commitment device for avoiding the inflation bias, familiar from Kydland and Prescott [26] and Barro and Gordon [3], associated with opportunistic behaviour. Central bank operational independence helps overcome the commitment problem either because the government selects 'conservative' central bankers or because opportunistic behaviour is, for whatever reason, not attractive to the operationally independent Central Bank. The cost to the Chancellor of taking Central Bank independence away, or for attempting to interfere with an operationally independent Central Bank is, greater than the cost to the Chancellor of acting opportunistically in the conduct of monetary policy when monetary policy is made by the Treasury.

The plausibility and empirical validity of the 'lack of commitment leads to inflation bias' argument have been questioned by Blinder [6]. McCallum [28] has pointed out that even if the inflation bias exists, it is incongruous to assume that the same Government that cannot commit itself credibly to a low inflation policy, is capable of appointing a monetary policy Agent capable of such commitment and of leaving the Agent alone The only argument that gets close to squaring this circle is based on Balcerowicz's proposition that during (rare) periods of "extraordinary politics", radical institutional changes and reforms can be introduced that are impossible to introduce during the (much 
more common) periods of "normal politics", and are not necessarily undone or reverse again during in the course of normal politics (Balcerowicz [2]). The creation of an operationally independent Central Bank with a clear inflation target during such a brief window of extraordinary politics could then have lasting effects on the conduct of monetary policy, even during periods when the creators of the operationally independent Central Bank have reverted to opportunistic 'politics as usual'.

\section{Conclusion}

Perhaps the title of this paper should have been : 'A Small but Important Corner of Intertemporal Public Finance'. I opted to omit he word 'important' to avoid encouraging a widespread tendency to overestimate the importance of monetary economics. The problem lies not with monetary theory. Despite the FTPL embarrassment, this is an exciting field of intellectual enquiry that forever raises more questions than we can hope to answer. The problem is with monetary policy - or rather with the exaggerated perception of its importance for economic performance. The educated general public too often stands in awe of central bankers. Too many central bankers' demeanor suggests that they view themselves as but one small step removed from divine status.

Keynes once expressed the hope that economists might someday be thought of like dentists - that they would be regarded as a-political professionals brought in to resolve technical problems ([24], p.332]). I would like to see Keynes's paradigm of the economist as dentist internalised by central 
bankers.

In a lecture given to celebrate the five-year jubilee of the UK inflation target, Mervyn King ([25]) gave the canonical description of what one might call the modern, technocratic view of central banking, that is, central banking as dentistry. His view that “... a successful central bank should be boring ..." ([25], p. 14) is very much in the spirit of Keynes's statement. Of course, being boring is only a necessary, not a sufficient condition for being an effective, successful central bank.

Too much survives still, especially outside the UK, of the traditional view of central bankers as priests and of central banks as their temple. In the priestly tradition, monetary policy is a cult whose high priests perform the sacred rites far from the prying eyes of the non-initiates. Frequent use of the phrase "constructive ambiguity" and regular recourse to uninterpretable Delphic utterances characterise the way the high priests of central banking address ordinary mortals. All this is dangerous from the perspective of effective economic management and unhealthy for political democracy. Monetary theory is intellectually exciting - and it is a fun subject. Monetary policy requires competent functionaries, capable of exercising in a transparent way the limited authority delegated to them. That should be enough.

\section{References}

[1] Allison, T. E. [1998], "Overall impact of euro banknotes on the demand for US currency", Testimony before the Subcommittee on Domestic and International Monetary Policy, Committee on Banking and Financial Services, U.S. House of Representatives October 8.

[2] Balcerowicz, L. [1995], Socialism, Capitalism, Transformation, CEU Press Budapest, London, New York. 
[3] Barro, R. J. and D. Gordon [1983], "A Positive Theory of Monetary Policy in a Natural Rate Model", Journal of Political Economy, 91, August, pp. 589-610.

[4] Begg, D. K. H. and B. Haque (1984), 'A Nominal Interest Rate Rule and Price Level Indeterminacy Reconsidered', Greek Economic Review, 6(1), pp. 31-46.

[5] Benassy, J.-P. [2003], "The Fiscal Theory of the Price Level Puzzle: A non Ricardian Resolution", mimeo, CEPREMAP, September.

[6] Blinder, A. [1999], Central Banking in Theory and Practice, MIT Press, Cambridge, Mass.

[7] Buiter, W. H. [2002], "The Fiscal Theory of the Price Level: A Critique", Economic Journal, 112, July, pp. 459-480.

[8] Buiter, W. H. [2003a], "Helicopter Money: Irredeemable Fiat Money and the Liquidity Trap", National Bureau of Economic Research Working Paper No. W10163, December 2003.

[9] Buiter, W. H. [2003b], "Two Naked Emperors? Concerns about the Stability and Growth Pact \& Second Thoughts about Central Bank Independence", forthcoming Fiscal Studies, September 2004.

[10] Buiter, W. H. and N. Panigirtzoglou [2001], "Liquidity Traps: How to Avoid Them and How to Escape Them", in Reflections on Economics and Econometrics, Essays in Honour of Martin Fase, edited by Wim F.V. Vanthoor and Joke Mooij, 2001, pp. 13-58, De Nederlandsche Bank NV, Amsterdam.

[11] Buiter, W. H. and N. Panigirtzoglou [2003], "Overcoming the Zero Bound on Nominal Interest Rates with Negative Interest on Currency: Gesell's Solution", Economic Journal, 113, October 2003, pp. 723-746.

[12] Buiter, W. H. and A. C. Sibert [2004], "Deflationary Bubbles", mimeo, EBRD, March.

[13] Cochrane, J. H. [1998], "A Frictionless model of U.S. Inflation," in Ben S. Bernanke and Julio J. Rotemberg, eds., NBER Macroeconomics Annual 1998 Cambridge MA: MIT press, pp. 323-384.

[14] Cochrane, J. H. [2001], "Long Term Debt and Optimal Policy in the Fiscal Theory of the Price Level", January, Econometrica 69, 69-116. 
[15] Cochrane, J. H. [2003], "Money as Stock", mimeo, June 27, Graduate School of Business, University of Chicago.

[16] Doyle, B. [2000], "'Here Dollars, Dollars . .': Estimating Currency Demand and Worldwide Currency Substitution," International Finance Discussion Paper 657 (Board of Governors of the Federal Reserve System).

[17] Drehmann, M., C. Goodhart and M. Krueger [2002], "The Challenges Facing Foreign Currency Usage: Will Traditional Transactions Medium Be Able to Resist Competition from New Technologies?" Economic Policy, Vol. 17, pp. 193-227.

[18] Fisher, I. [1933], Stamp Scrip, Adelphi Company, New York.

[19] Friedman, B. [2001], "Decoupling at the Margin: The Threat to Monetary Policy from the Electronic Revolution in Banking." International Finance, 3 (July, 2001).

[20] Friedman, B. [2002], "Threats to the Future Effectiveness of Monetary Policy." Cooper and Layard (eds.), What the Future Holds: Insights from Social Science. Cambridge: MIT Press, 2002.

[21] Friedman, M. [1969], "The Optimum Quantity of Money", in Milton Friedman, The Optimum Quantity of Money and Other Essays, Chapter 1, pp.1-50, Adline Publishing Company, Chicago.

[22] Gesell, S. [1949], Die Natuerliche Wirtschaftsordnung, Rudolf Zitzman Verlag, available in English as The Natural Economic Order, Peter Owen Ltd, London, 1958.

[23] Goodfriend, M. [2000], "Overcoming the Zero Bound on Interest Rate Policy", Journal of Money, Credit and Banking, Vol. 32, No. 4, Pt. 2, November, 1007-1035.

[24] Keynes, J. M. [1931], "Economic Possibilities for our Grandchildren", in John Maynard Keynes, Essays in Persuasion, Macmillan Press Ltd. London, 321-332.

[25] King, M. [1997], "The Inflation Target Five Years On", Lecture delivered at the London School of Economics, Wednesday 29 October. Bank of England mimeo. 
[26] Kydland, F. E. and E. C. Prescott [1977], "Rules Rather Than Discretion: The Inconsistency of Optimal Plans", Journal of Political Economy, 85, June, pp. 473-492.

[27] Kocherlakota, N. and C. Phelan [1999], "Explaining the Fiscal Theory of the Price Level," Federal Reserve Bank of Minneapolis Quarterly Review, 23, pp. 14-23.

[28] McCallum, B. T. [1995], "Two Fallacies Concerning Central Bank Independence," American Economic Review, Papers and Proceedings 85, May, 207-211.

[29] McCallum, B. T. [2001], "Indeterminacy, Bubbles, and the Fiscal Theory of the Price Level," Journal of Monetary Economics 47, February, 19-30.

[30] McCallum, B. T. [2003a], "Monetary Policy in Economies with Little or No Money", NBER Working Paper w9838, July.

[31] McCallum, B. T. [2003b], "Is the Fiscal Theory of the Price Level Learnable?", NBER Working Paper w9961, September.

[32] Niepelt, D. [2004], "The Fiscal Myth of the Price Level", Quarterly Journal of Econoics, Volume 119(1), February, pp. 277-300.

[33] Rogoff, K. [1998], "Foreign and Underground Demand for Euro Notes: Blessing or Curse?" Economic Policy, Vol. 26 (April), pp. 263-303.

[34] Rogoff, K. [2002], "The Surprising Popularity of Paper Currency", Finance and Development, Volume 39, March, Number 1.

[35] Sargent, T.J. and N. Wallace [1981], "Some Unpleasant Monetarist Arithmetic", Federal Reserve Bank of Minneapolis, Quarterly Review, Vol. 5(3).

[36] Sibert, A. C. [2003], "Monetary Policy Committees: Individual and Collective Reputations," Review of Economic Studies, 70, Jul., 649-666.

[37] Sibert, A. C. [2004], "Is the Structure of the ECB Adequate to the New Challenge?", mimeo, Birkbeck College, University of London, February.

[38] Sibert, A. C. and I..Mihov [2003], "Credibility and Flexibility with Monetary Policy Committees," mimeo Oct.

[39] Sims, C. A. [1994], "A Simple Model for Study of the Determination of the Price Level and the Interaction of Monetary and Fiscal Policy," Economic Theory 4, pp. 381-399. 
[40] Sims, C. A. [1997], "Econometric Implications of the Government Budget Constraint", Journal of Econometrics, 1997.

[41] Sims, C. A. [1999], "Domestic Currency Denominated Government Debt as Equity in the Primary Surplus", mimeo, Princeton University.

[42] Sims, C. A. [2001], "Fiscal Consequence for Mexico Adopting the Dollar," Journal of Money, Credit and Banking, 23, pp. 597-625.

[43] Svensson, L. E. O. [2003], "Escaping from a liquidity trap and deflation: the foolproof way and others", NBER Working Paper 10195, December.

[44] Weil, P. [1991], "Is Money Net Wealth?", International Economic Review, 32, February, pp. 37-53.

[45] Woodford, M. [1995], "Price Level Determinacy without Control of a Monetary Aggregate," Carnegie-Rochester Conference Series on Public Policy 43: 1-46 (1995).

[46] Woodford, M. [1997], "Control of the Public Debt: A Requirement for Price Stability?" in G. Calvo and M. King, eds., The Debt Burden and Monetary Policy, London: Macmillan, 1997.

[47] Woodford, M. [1998a], "Comment on John Cochrane, 'A Frictionless View of U.S. Inflation'," NBER Macroeconomics Annual 1998, pp. 390418.

[48] Woodford, M. [1998b], "Public Debt and the Price Level," mimeo, Princeton University Department of Economics, June.

[49] Woodford, M. [2001], "Fiscal Requirements for Price Stability," Journal of Money, Credit and Banking 33: 669-728 (2001).

[50] Woodford, M. [2003], Interest and Prices; Foundations of a Theory of Monetary Policy, Princeton University Press, Princeton. 